\title{
METABOLISM OF TESTICULAR SPERMATOZOA AND CHARACTERISTICS OF TESTICULAR FLUID COLLECTED FROM CONSCIOUS RAMS
}

\author{
J. K. VOGLMAYR, T. W. SCOTT*, B. P. SETCHELL AND \\ G. M. H. WAITES $\uparrow$ \\ C.S.I.R.O., Division of Animal Physiology, Ian Clunies Ross Animal \\ Research Laboratory, Prospect, New South Wales, Australia
}

(Received 23rd May 1966, revised 5th July 1966)

\begin{abstract}
Summary. A procedure is described for the collection of spermatozoa and fluid from the testes of conscious rams over long periods of time. Spermatozoa and fluid are produced at a steady rate. The fluid is isosmotic with blood plasma but contains more potassium and less sodium. Testicular spermatozoa differ from ejaculated spermatozoa by converting a higher percentage of the utilized glucose to carbon dioxide and a lower percentage to lactic acid. They are resistant to cold shock, and can be stored at $1^{\circ} \mathrm{C}$ in testicular fluid for up to 6 days without significant mortality. The metabolic pattern of stored testicular spermatozoa resembles that of ejaculated spermatozoa, but differs from that of freshly collected testicular spermatozoa. Freshly collected testicular spermatozoa are immotile, but a small degree of motility can be induced either by increasing the $\mathrm{pH}$ of testicular fluid to between 7.5 and 8.5 , or by storage at $1^{\circ} \mathrm{C}$ in testicular fluid. The immotility of fresh testicular spermatozoa is not due to lack of adenosine triphosphate since this compound is present in similar concentrations in both testicular and ejaculated spermatozoa. No evidence was obtained for the presence of a pentose cycle (hexose monophosphate shunt) in either testicular or ejaculated spermatozoa. Testicular fluid stimulates the oxygen uptake of both kinds of spermatozoa.
\end{abstract}

\section{INTRODUGTION}

It is well established that spermatozoa undergo distinct morphological and physiological changes during their passage through the epididymal duct, a process referred to as 'maturation' (Bishop \& Walton, 1960; Mann, 1964; Bishop, 1961).

In an attempt to understand this process, the composition of the fluid in the testis and epididymis (Salisbury \& Cragle, 1956; Dawson, Mann \& White, 1957; Dawson \& Rowlands, 1959; Scott, Wales, Wallace \& White, 1963;

* Queen Elizabeth II Fellow.

$\dagger$ Present address: Department of Physiology, University of Sydney, Sydney, New South Wales, Australia. 
Crabo \& Gustafsson, 1964; Crabo, 1965) and the metabolism of epididymal and testicular spermatozoa (Redenz, 1933; Henle \& Zittle, 1942; Lardy, Hansen \& Phillips, 1945; Wu, McKenzie, Fang \& Butts, 1959; White \& Wales, 1961) have been studied. However, in most instances, the material examined was obtained from animals at slaughter and, despite precautions, the results were conflicting. Ideally, the testicular secretion, i.e. spermatozoa and fluid, should be collected directly and continuously from the testis before coming in contact with fluid secreted by the epididymis. A technique suitable for this purpose is described in the ram, together with observations on the metabolism of the spermatozoa and composition of the fluid collected from the testis (Voglmayr, Waites \& Setchell, 1966).

\section{MATERIALS AND METHODS}

Animals

Nine Merino rams ( 3 to 5 years old) weighing 50 to $60 \mathrm{~kg}$ were fed on an unrestricted diet of chaffed lucerne hay and oats $(1: 1)$. The animals were made to stand in cages in controlled environment $\left(21^{\circ} \mathrm{C} ; 12 \mathrm{hr}\right.$ of light/day).

\section{Collection of spermatozoa}

Testicular spermatozoa. The general surgical procedure was as described by Waites \& Setchell (1964). The dorsal pole of the testis was exposed through an incision on the lateral surface of the scrotum and by opening the tunica vaginalis. The head of the epididymis was then dissected from the tunica albuginea until the efferent tubules were exposed. After careful dissection around the tubules, two ligatures were passed behind them. Using one of these to steady the tubules, a vertical incision was made with a scalpel so that the silicone rubber catheter $(0.5 \mathrm{~mm}$ I.D., $1.0 \mathrm{~mm}$ O.D., $32 \mathrm{~cm}$ long; Ludowici \& Sons Ltd, Lane Cove, New South Wales) could be inserted until the cuff (C, Text-fig. 1) was just inside the tubules. The catheter was secured by the second ligature around all the efferent tubules above the cuff and brought to the exterior through the incision (Plate 1). Kinking was prevented by packing gelatin sponge (Sterispon, Allen \& Hanbury's, London) around the tubules and the catheter. The secretion from the testis was collected into a polyethylene receptacle attached to the scrotum.

Ejaculated spermatozoa. Semen was collected by electro-ejaculation using the apparatus described by Blackshaw (1954).

\section{Preparation and incubation of spermatozoal suspensions}

Testicular spermatozoa were separated by centrifugation at $450 \mathrm{~g}$ for $5 \mathrm{~min}$ from the testicular secretion collected during $4 \mathrm{hr}$. Ejaculated spermatozoa were separated from semen diluted with 9 volumes of an appropriate diluent, and centrifuged at $450 \mathrm{~g}$ for $8 \mathrm{~min}$. Both types of spermatozoa were then resuspended in diluent and centrifuged again. The supernatant was removed, the spermatozoa were resuspended, counted in a haemocytometer and diluted to the desired concentration with the incubation medium. The spermatozoal suspensions were incubated in air in Warburg flasks $(6 \mathrm{ml})$ at $37^{\circ} \mathrm{C}$ with a shaking 
rate of $60 \mathrm{cycles} / \mathrm{min}$. Duplicate incubations were made on spermatozoa from at least two rams and all values were expressed on a basis of live spermatozoa as judged by nigrosin-eosin staining before incubation (Hancock, 1952).

\section{Diluents and substrates}

Spermatozoa were incubated in either the sodium-potassium phosphate diluent of White (1953) (phosphate buffer), or in the phosphate-free Ringer (Mann, 1945), buffered with tris (2-amino-2-hydroxymethylpropane-1:3-diol)HCl $(0.05 \mathrm{~m})$. Radio-active D-glucose $\left(\left[\mathrm{U}-{ }^{14} \mathrm{C}\right],\left[1-{ }^{14} \mathrm{C}\right]\right.$ and $\left.\left[6-{ }^{14} \mathrm{C}\right]\right)$ was obtained from the Radiochemical Centre, Amersham, Buckinghamshire,

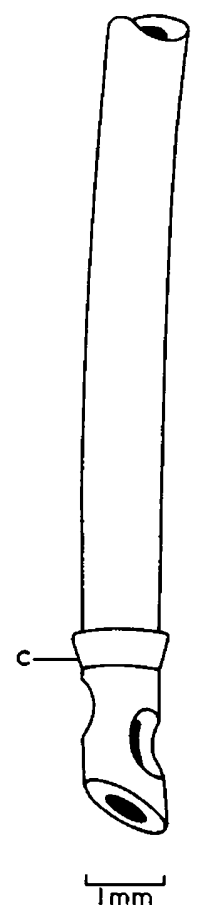

TeXT-FIG. 1. Diagram of the catheter used for collecting testicular spermatozoa. G, Cuff.

and its purity was checked by chromatographic procedures (see below). Labelled substrates were added to the media to yield a final concentration of $1.25 \mu \mathrm{C}$ and $600 \mu \mathrm{g} /$ flask.

\section{Analytical procedures}

Oxygen uptake was measured at $30 \mathrm{~min}$ intervals throughout the incubation period. Radio-active carbon dioxide was collected by the method of Buhler (1962). Following incubation, the glucose and lactate present in the cell-free supernatant were assayed by chromatographic procedures (Freinkel, Cohen, Arky \& Foster, 1965). Both glucose and lactate were also determined by enzymic methods (Huggett \& Nixon, 1957; Lundholm, Mohme-Lundholm \& Vamos, 1963). Radio-activity was measured using an automatic liquid scintil- 
lation spectrometer (Packard Instrument Co., La Grange, Illinois, U.S.A.). Sodium and potassium were measured by flame photometry (EEL, Evans Electroselenium Ltd, Harlow, Essex, England), and osmolality by determining the freezing point depression (Osmometer, Advanced Instruments, Inc., Newton Highlands, Massachusetts, U.S.A.).

For analysis of adenosine mono-, di- and tri-phosphate, testicular and ejaculated spermatozoa were collected from the same animal into receptacles containing formalin (final concentration of approximately $0.03 \% \mathrm{v} / \mathrm{v}$ ). The nucleotides were extracted from the cells by the procedure of Newton \& Rothschild (1961) and separated by the method of Bergkvist \& Deutsch (1954) as modified by Newton \& Perry (1960). Lipids were extracted by the technique described by Scott, Dawson \& Rowlands (1963). Radio-activity was measured in the liquid scintillation counter by evaporating samples to dryness in counting vials and redissolving the residue in toluene-methanol scintillator [ 6 parts methanol: 100 parts toluene containing $0.4 \% \mathrm{w} / \mathrm{v} 2: 5$-diphenyl oxazole and $0.01 \% \mathrm{w} / \mathrm{v}$ 1:4-bis-2-(5-phenyloxazolyl)-benzene].

\section{Cold shock and storage of testicular spermatozoa}

Freshly collected testicular and ejaculated spermatozoa were subjected to cold shock as described by Hancock (1951). Testicular spermatozoa collected over a 16-hr period were stored at $1^{\circ} \mathrm{C}$ in the fluid in which they were secreted. After 1, 3, 6, 9 and 12 days the spermatozoal suspension was gently agitated, and a portion allowed to warm to room temperature. Spermatozoa were then separated and incubated as described above. During storage the degree of bacterial contamination was assessed by incubation of the washed spermatozoal suspension on MacConkey's and blood agar plates (Mackie \& McCartney, 1949) for 3 days at $37^{\circ} \mathrm{C}$.

\section{RESULTS}

\section{Production of spermatozoa and fluid by the ram testis}

The output of fluid and spermatozoa from all testes was steady except for the first 1 to 3 days after operation, when sometimes unaccountable fluctuations occurred (Text-fig. 2). The catheters remained patent for 10 to 120 days and the concentration of spermatozoa varied in an approximately inverse proportion with the volume of fluid secreted so that total daily output of spermatozoa remained reasonably constant (Text-fig. 2). Negligible contamination with cells other than spermatozoa was observed in the testicular secretion, in fact there was less contamination with other cells than in ejaculated semen (Plate 2). Little variation occurred in the osmolality or in the concentration of sodium and potassium in the fluid from seven rams. When compared with plasma (P), the concentration of potassium in testicular fluid (TF) was about three times higher [P: $4.18 \mathrm{mEq} / \mathrm{l}$ (sixteen observations), s.D. within rams $\pm 0 \cdot 80$; s.D. between rams \pm 0.54 . TF: $12.7 \mathrm{mEq} / 1$ (thirty-two), $\pm 1.20 ; \pm 5.5]$, whereas sodium was present in lower concentrations [P: $144 \mathrm{mEq} / \mathrm{l}$ (sixteen), \pm 3.0 ; \pm 4.5 . TF: $133 \mathrm{mEq} / \mathrm{l}$ (thirty-two), $\pm 7 \cdot 9 ; \pm 5 \cdot 3]$. However there was no consistent difference in the osmolality $[\mathrm{p}: 298 \mathrm{mOsm} / \mathrm{l}$ (sixteen), $\pm 7 \cdot 7 ; \pm 8 \cdot 1$. TF : $283 \mathrm{mOsm} / 1$ (eighteen) $\pm 6 \cdot 7 ; \pm 20 \cdot 0]$. 


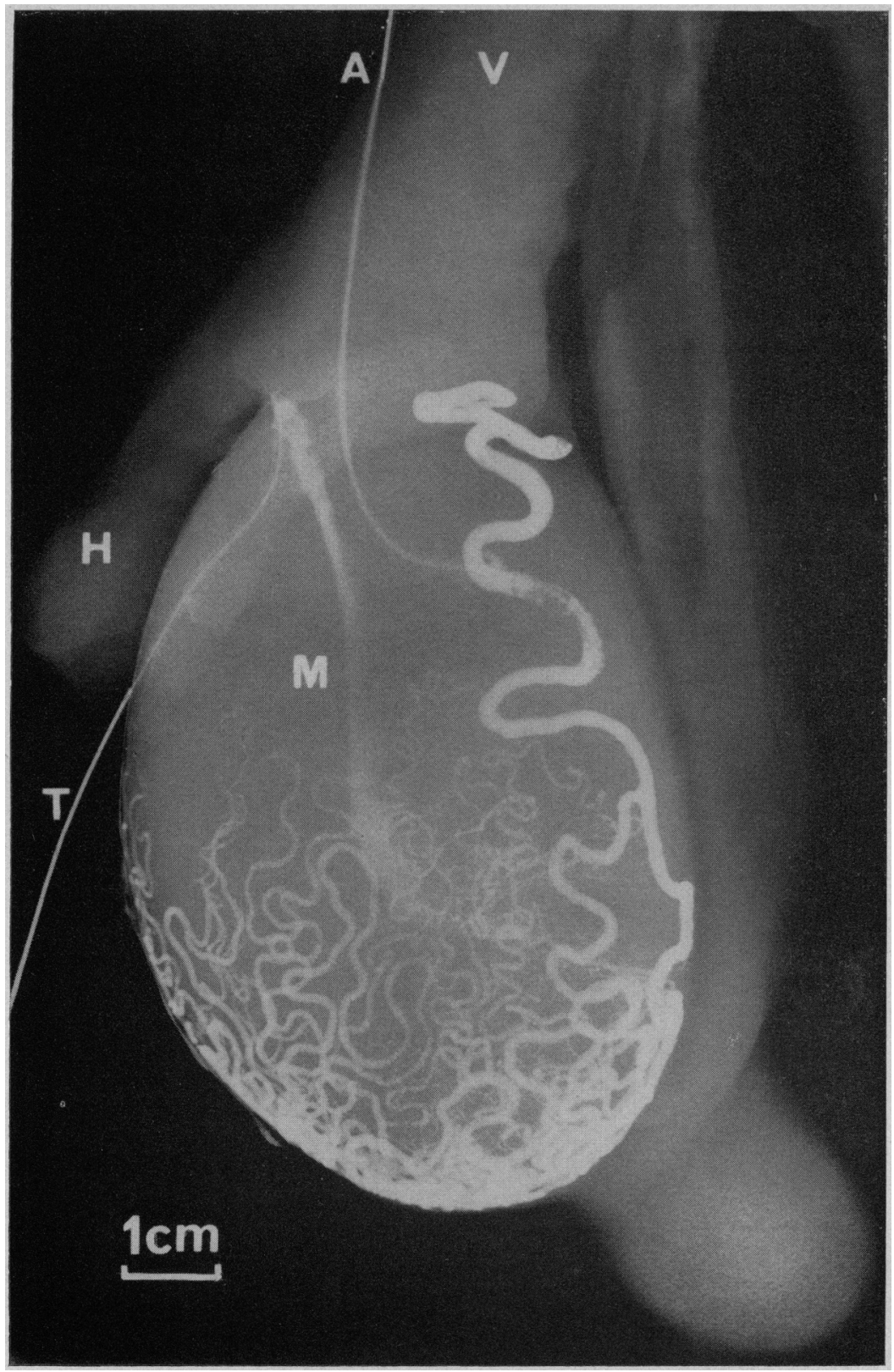

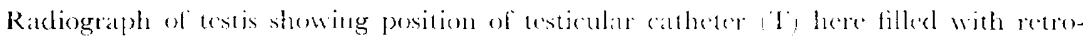

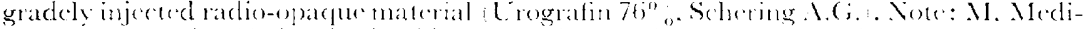

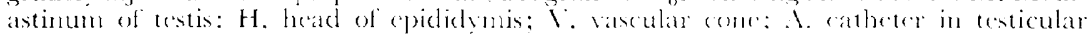

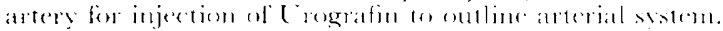


11.111:
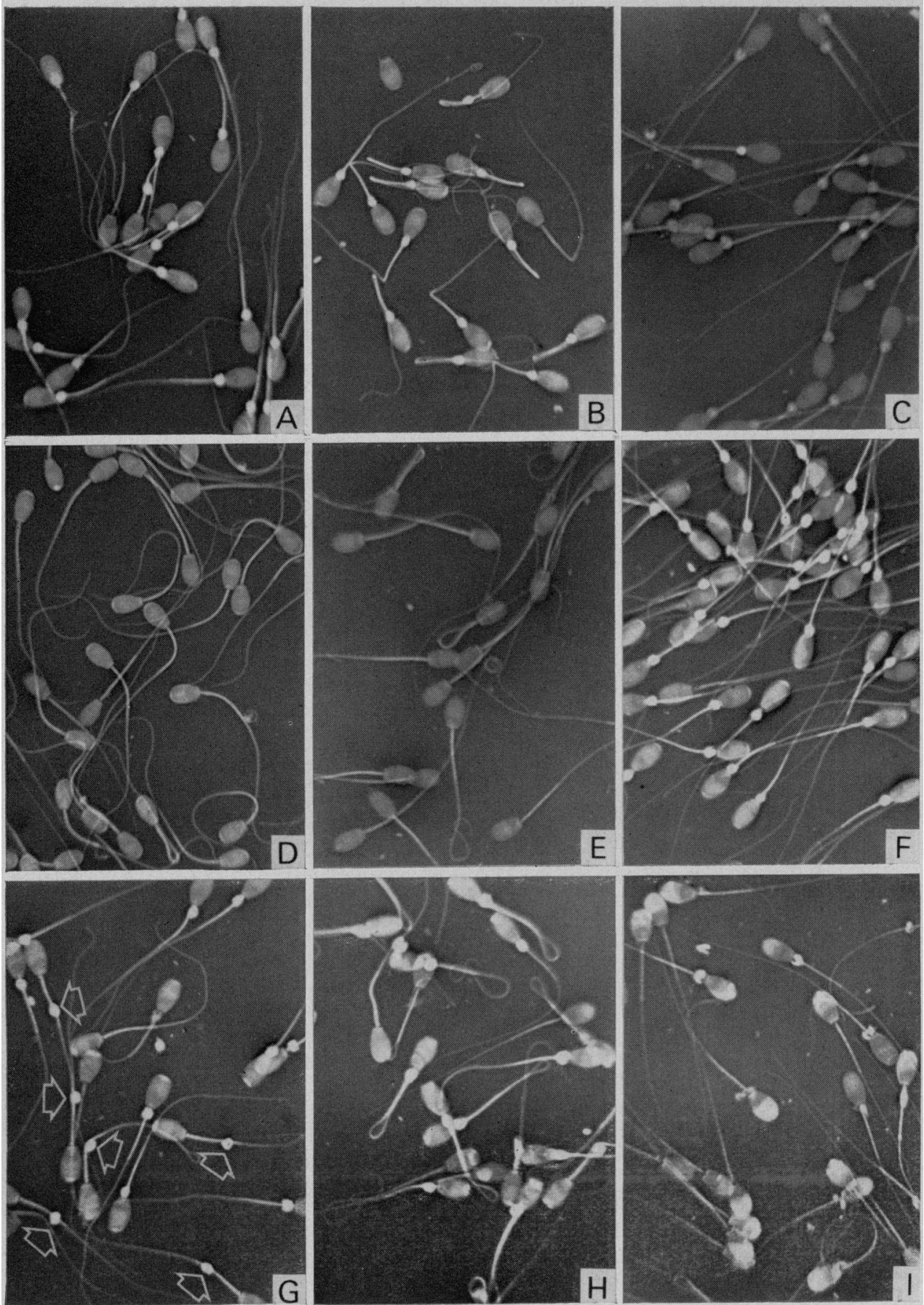

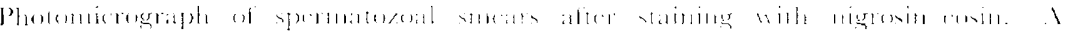

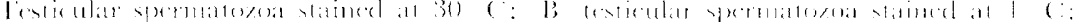

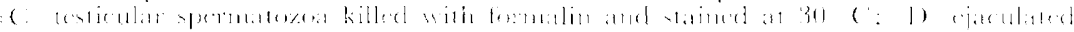

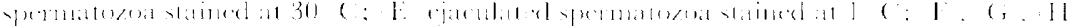

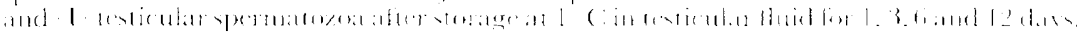

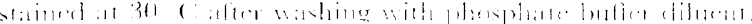


Incubation of testicular and ejaculated spermatozoa in synthetic media

There were considerable differences in the oxidative and glycolytic dissimilation of glucose by testicular and ejaculated spermatozoa when suspended in either phosphate buffer or phosphate-free Ringer.

Oxygen uptake. The oxygen uptake of testicular spermatozoa in the absence of added substrate was always linear in both phosphate buffer and phosphatefree Ringer. This is in contrast to the ejaculated cells collected from the same ram (Text-fig. 3). The endogenous oxygen uptake of ejaculated spermatozoa was similar in the two diluents, whereas testicular spermatozoa used more oxygen in phosphate-free Ringer (Text-fig. 3 ).

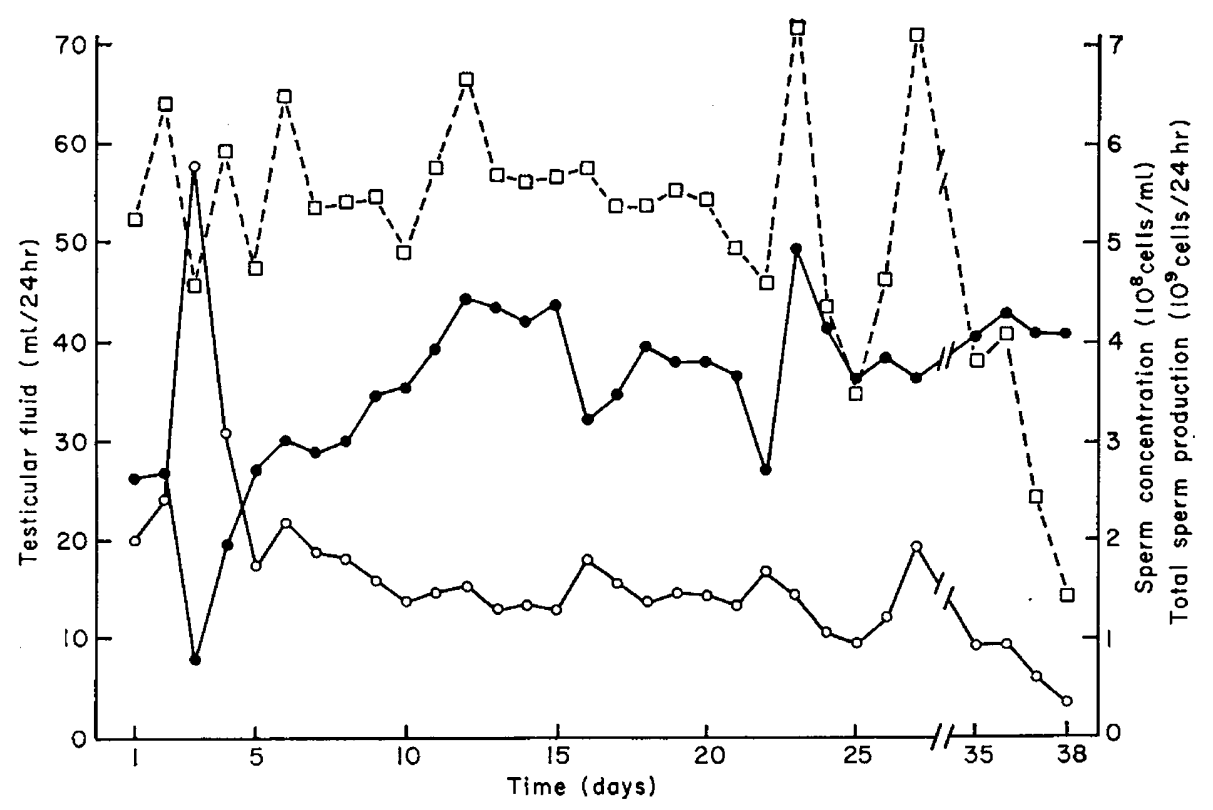

TEXT-FIG. 2. Spermatozoa ( $\square$ ) and fluid production (๑) and spermatozoal concentration $(O)$ in the secretion collected from the testis $(209 \mathrm{~g})$ of a Merino ram over 38 days. No measurements were made between the 27 th and 35 th day.

The addition of glucose to the media always caused a significant increase in the oxygen uptake except when testicular spermatozoa were incubated in phosphate-free Ringer (Text-fig. 3). The initial rate of respiration in the presence of glucose in phosphate buffer was similar for both types of spermatozoa but decreased progressively in ejaculated cells. In phosphate-free Ringer, on the other hand, the respiration of ejaculated spermatozoa in the presence of glucose was linear throughout the incubation period (Text-fig. 3).

Glucose metabolism. The uptake of glucose by testicular spermatozoa was always less than by ejaculated cells from the same ram in both diluents; a much smaller fraction of the glucose utilized by testicular spermatozoa accumulated as lactate. In contrast, the percentage of glucose converted to carbon dioxide by the two cell types was similar during the lst $\mathrm{hr}$ of incubation but continued to increase with the testicular spermatozoa so that for a 3-hr incubation 
there was a striking difference. This increase was much more apparent in phosphate buffer than in phosphate-free Ringer, where ejaculated cells also showed an increase in the percentage of glucose converted to carbon dioxide as the time of incubation increased (Table 1).

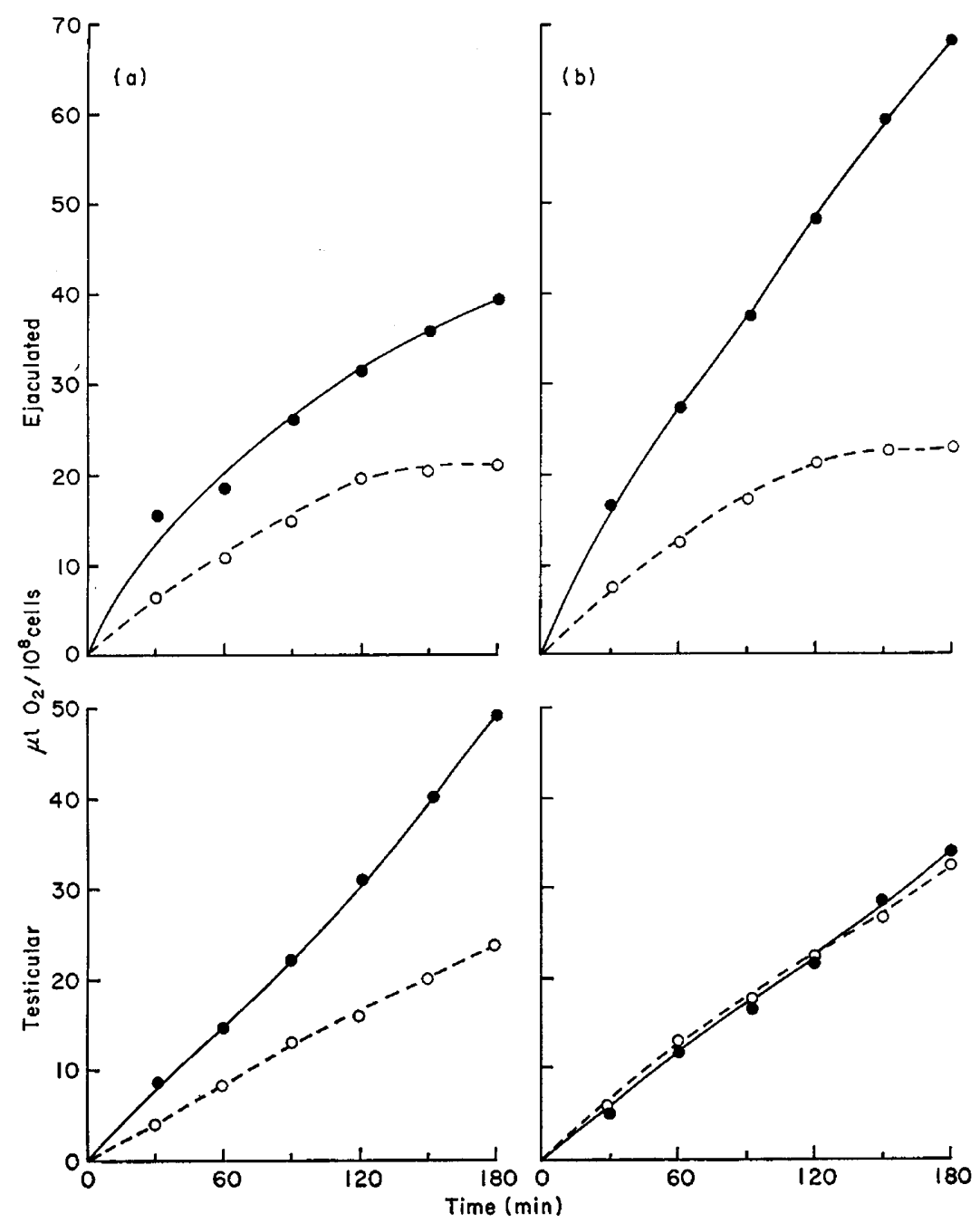

TExT-FIG. 3. Oxygen uptake of washed ejaculated and testicular spermatozoa from the same ram incubated in: (a) phosphate buffer diluent, or (b) phosphate-free Ringer buffered with $0.05 \mathrm{M}$ tris. $\mathrm{O}$, With glucose $(0.004 \mathrm{M})$; $O$, endogenous. Further details see text.

The radio-activity in carbon dioxide and lactate accounted for about $90 \%$ of the glucose utilized by ejaculated spermatozoa. However, when testicular spermatozoa were incubated for $1 \mathrm{hr}$ in phosphate buffer or for 2 or $3 \mathrm{hr}$ in phosphate-free Ringer, about half the radio-active glucose utilized could not be accounted for either as carbon dioxide or lactate, but appeared on the 
chromatogram with a $R_{\mathrm{F}}=0.2$ to 0.3 between the origin and the glucose $\left(R_{\mathrm{F}}=0.62\right)$.

Pentose cycle. Spermatozoa were incubated with glucose labelled specifically in the $\mathrm{C}_{1}$ and $\mathrm{C}_{6}$ positions and the specific yields of carbon dioxide (as defined by Wood, Katz \& Landau, 1963) were calculated. Estimates were also made of the radio-activity in lactate and total lipid. The similarity of the values for $\mathrm{C}_{1}$ and $\mathrm{C}_{6}$ glucose indicated that the metabolism of glucose through the pentose cycle (hexose monophosphate shunt activity) was negligible in both cell types (Table 2).

More radio-active carbon dioxide and slightly more lactate were formed by testicular spermatozoa incubated with uniformly labelled glucose than with glucose labelled in the $\mathrm{C}_{1}$ or $\mathrm{C}_{6}$ positions.

TABLE 1

METABolism of [U- ${ }^{14} \mathrm{C}$ ] GLUGOSE By TESTicular (T) AND EJAGUlated (E) RAM SPERMATOZOA

\begin{tabular}{|c|c|c|c|c|c|c|c|}
\hline \multirow{2}{*}{ Diluent } & \multirow{2}{*}{$\begin{array}{l}\text { Incubation } \\
\text { time (min) }\end{array}$} & \multicolumn{2}{|c|}{$\begin{array}{l}\text { Glucose uptake* } \\
\left(\mu g / 10^{8} \text { cells }\right)\end{array}$} & \multicolumn{2}{|c|}{$\begin{array}{l}\text { Lactate } \\
(\% \text { glucose uptake })\end{array}$} & \multicolumn{2}{|c|}{$\begin{array}{c}\text { Carbon dioxide } \\
(\% \text { glucose uptake })\end{array}$} \\
\hline & & $T$ & $E$ & $T$ & $E$ & $T$ & $E$ \\
\hline Phosphate buffer diluent & $\begin{array}{r}60 \\
120 \\
180\end{array}$ & $\begin{array}{r}73 \\
85 \\
165\end{array}$ & $\begin{array}{l}166 \\
243 \\
312\end{array}$ & $\begin{array}{l}42 \cdot 5 \\
54 \cdot 1 \\
47 \cdot 9\end{array}$ & $\begin{array}{l}66 \cdot 3 \\
87 \cdot 2 \\
83 \cdot 0\end{array}$ & $\begin{array}{l}12 \cdot 3 \\
28 \cdot 2 \\
30 \cdot 3\end{array}$ & $\begin{array}{l}11.4 \\
10.7 \\
11.9\end{array}$ \\
\hline Phosphate-free 'Ringer' & $\begin{array}{r}60 \\
120 \\
180\end{array}$ & $\begin{array}{l}5 \overline{8} \\
81\end{array}$ & $\begin{array}{l}205 \\
284 \\
337\end{array}$ & $\begin{array}{c}3 \overline{6 \cdot} \cdot 2 \\
40 \cdot 7\end{array}$ & $\begin{array}{l}79 \cdot 5 \\
73 \cdot 6 \\
64 \cdot 6\end{array}$ & $\begin{array}{c}\overline{17 \cdot 2} \\
23 \cdot 5\end{array}$ & $\begin{array}{l}10 \cdot 2 \\
14.8 \\
17.8\end{array}$ \\
\hline
\end{tabular}

Testicular and ejaculated spermatozoa (approximately $10^{8}$ cells/flask in $0.6 \mathrm{ml}$ of media) obtained from the same ram, were incubated as described in the text. Values reported are the means for two animals.

* Glucose uptake equals initial minus final amount present.

Lactate $\left({ }^{14} \mathrm{C}\right)$ present in the media at the end of incubation and carbon dioxide $\left({ }^{14} \mathrm{CO}_{2}\right)$ collected into $\mathrm{KOH}(10 \% \mathrm{w} / \mathrm{v})$ in centre well.

\section{Incubation of spermatozoa in testicular fluid}

The oxygen uptake of testicular spermatozoa in testicular fluid was higher than in phosphate buffer without added substrate, although it did not remain linear as it did in phosphate buffer with glucose. In contrast, the oxygen uptake of ejaculated spermatozoa in testicular fluid was higher than in phosphate buffer with or without glucose (Text-fig. 4). This stimulatory effect cannot be explained by the amount of glucose or lactate present in testicular fluid (Voglmayr et al., 1966).

\section{Cold shock}

Testicular spermatozoa were strikingly more resistant to sudden cooling to temperatures as low as $1^{\circ} \mathrm{C}$ than were ejaculated spermatozoa (Plate $2 \mathrm{~A}$, $\mathrm{B}, \mathrm{D}$ and $\mathrm{E}$ ). The nigrosin-eosin mixture stained approximately $5 \%$ of the testicular spermatozoa at $30^{\circ} \mathrm{C}$, whereas at $1^{\circ} \mathrm{C}$, about $20 \%$ of the testicular spermatozoa were stained. In contrast, as few as $5 \%$ of ejaculated spermatozoa 


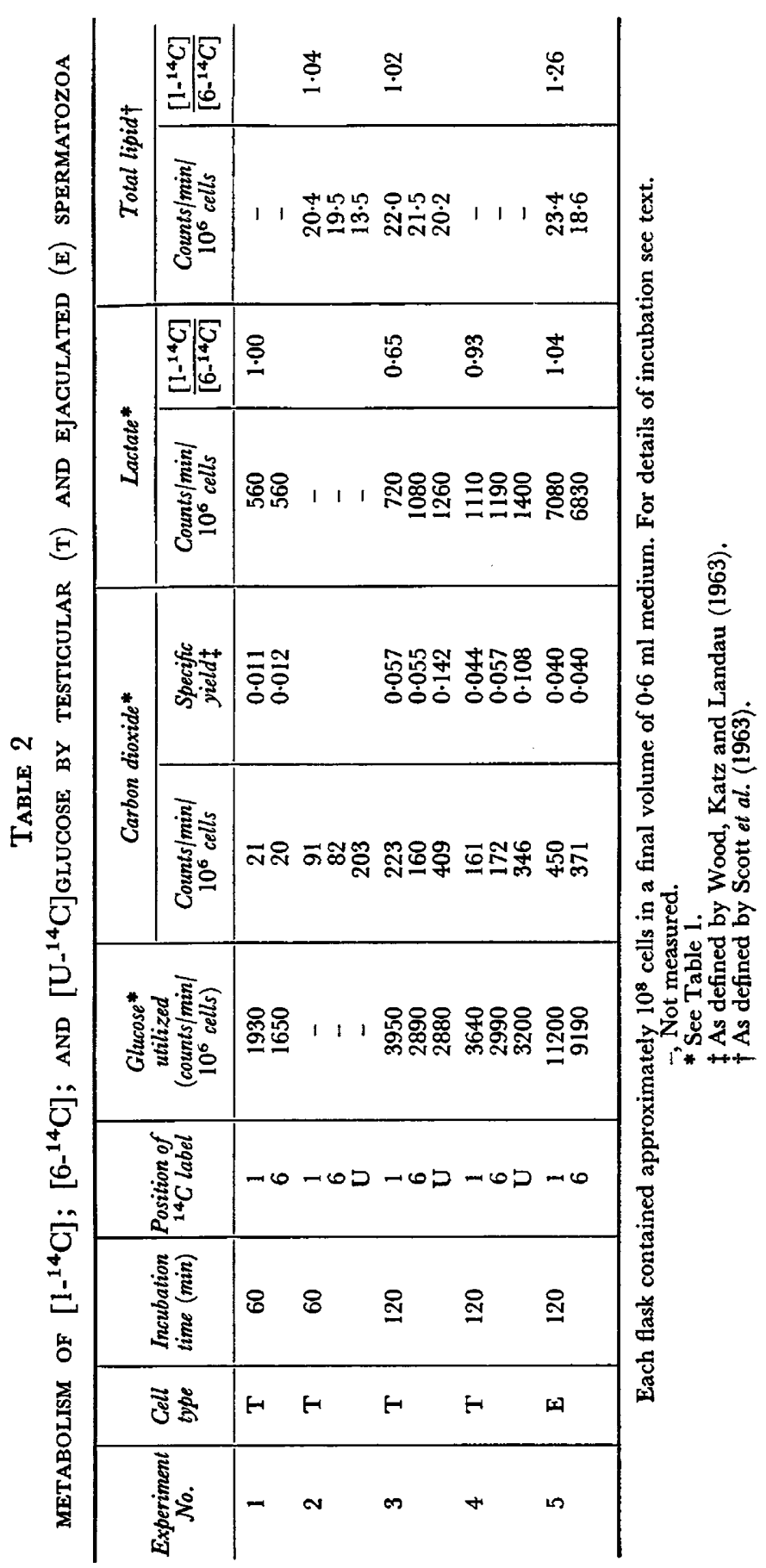


were stained at $30^{\circ} \mathrm{C}$, but all stained at $1^{\circ} \mathrm{C}$. This difference was not due to the inability of dead testicular spermatozoa to take up stain as testicular spermatozoa killed with formalin were readily stained (Plate $2 \mathrm{C}$ ). However, many testicular spermatozoa suddenly cooled to $1^{\circ} \mathrm{C}$ were kinked at the junction of the mid-piece and tail (Plate 2 B).

Storage of testicular spermatozoa

The evidence that testicular spermatozoa were resistant to cold was supported by the persistence of their metabolic activity after prolonged storage in testicular fluid at $1^{\circ} \mathrm{C}$. Indeed, after 3 days storage, oxygen uptake was higher than in freshly collected testicular spermatozoa when both were incubated at

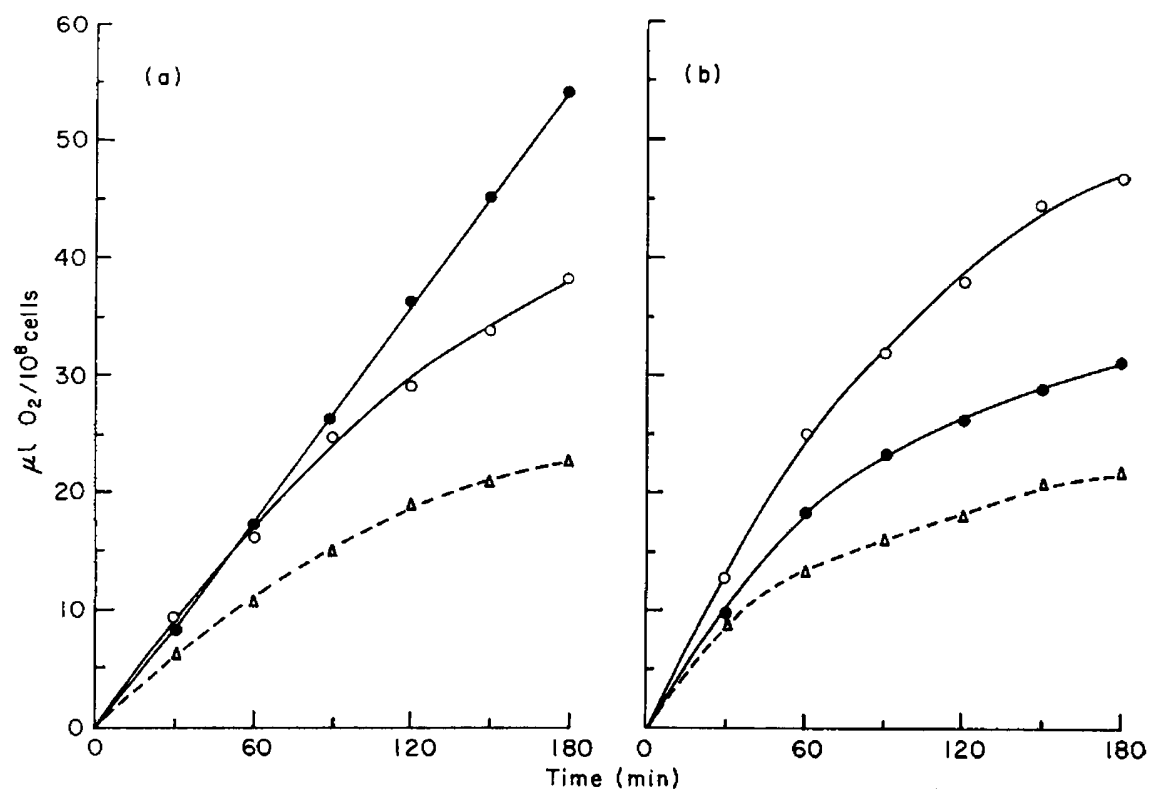

TexT-Fig. 4. The oxygen uptake of: (a) washed testicular, and (b) ejaculated ram spermatozoa from the same ram, incubated in testicular fluid $(O)$ or in phosphate buffer with glucose $0.004 \mathrm{M}(\bullet)$ or with no added substrate $(\Delta)$. Values at each time point are the means of duplicate incubations for two animals.

$37^{\circ} \mathrm{C}$ in phosphate buffer containing glucose. However, after prolonged storage at $1^{\circ} \mathrm{C}$ respiration declined and was only about $30 \%$ of the initial value after 12 days storage. The most outstanding effect of storage on the metabolism of testicular spermatozoa was the change in the amount of glucose utilized. After storage for 6 days at $1^{\circ} \mathrm{C}$ there was about a three-fold increase above the original value; after 12 days storage, the spermatozoa did not metabolize any added glucose (Table 3). Nevertheless, the amount of glucose converted to carbon dioxide by testicular spermatozoa decreased with storage; the oxygen uptake reached a peak at 3 days and then declined with further storage. The amount of lactate produced by testicular spermatozoa during incubation at $37^{\circ} \mathrm{C}$ was greater after storage at $1^{\circ} \mathrm{C}$, but accounted for approximately 
the same proportion of the glucose utilized. Similar results were obtained when spermatozoa from a third animal were incubated after storage for 6 days. As in freshly collected testicular spermatozoa, almost all of the radio-activity not accounted for as lactate or carbon dioxide appeared on the chromatogram between the origin and the glucose. By 12 days there was no detectable lactate present in the media following incubation. No significant bacterial contamination was detected.

The majority of testicular spermatozoa stored at $1^{\circ} \mathrm{C}$ for up to 6 days were not stained with nigrosin-eosin (Plate 2 F, G and H) and the kinoplasmic droplet had moved away from the head of some spermatozoa. More spermatozoa

TABLE 3

METABOLISM OF $\left[\mathrm{U}-{ }^{14} \mathrm{C}\right]$ GLUCOSE BY TESTIGULAR RAM SPERMATOZOA INGUBATED AT $37^{\circ} \mathrm{C}$ after Storage at $1^{\circ} \mathrm{C}$

\begin{tabular}{|c|c|c|c|c|c|}
\hline $\begin{array}{c}\text { Time of storage } \\
\quad(\text { days })\end{array}$ & $\begin{array}{l}\text { Oxygen uptake } \\
\left(\mu l / 10^{8} \text { cells }\right)\end{array}$ & $\begin{array}{l}\text { Glucose uptake } \\
\left(\mu g / 10^{8} \text { cells }\right)\end{array}$ & $\begin{array}{c}\text { Lactate } \\
(\% \text { glucose uptake })\end{array}$ & $\begin{array}{c}\text { Carbon dioxide } \\
(\% \text { glucose uptake })\end{array}$ & Motility* \\
\hline $\begin{array}{c}\text { Ram } 1 \\
0 \\
1 \\
3 \\
6 \\
12\end{array}$ & $\begin{array}{l}49 \\
56 \\
76 \\
52 \\
13\end{array}$ & $\begin{array}{r}123 \\
90 \\
184 \\
311 \\
0\end{array}$ & $\begin{array}{r}51 \\
26 \\
29 \\
48 \\
-\end{array}$ & $\begin{array}{r}31 \\
45 \\
35 \\
15 \\
-\end{array}$ & $\begin{array}{r}r+ \\
++ \\
++t \\
++ \\
0\end{array}$ \\
\hline $\begin{array}{c}\text { Ram } 2 \\
0 \\
1 \\
3 \\
6 \\
9\end{array}$ & $\begin{array}{l}60 \\
70 \\
85 \\
34 \\
17\end{array}$ & $\begin{array}{r}98 \\
101 \\
350 \\
560 \\
39\end{array}$ & $\begin{array}{l}31 \\
35 \\
43 \\
43 \\
56\end{array}$ & $\begin{array}{r}45 \\
63 \\
21 \\
5 \\
8\end{array}$ & $\begin{array}{r}<+ \\
++ \\
+++ \\
++ \\
+\end{array}$ \\
\hline
\end{tabular}

Duplicate incubations for $3 \mathrm{hr}$ in phosphate buffer were made of testicular spermatozoa from two rams: details of storage and incubation are given in text. For explanation of captions see Table 1 .

* Motility assessed after washing is given in arbitrary units $(+$, etc.), but the scale used represents a much lower degree of motility than in similar scales used for ejaculated spermatozoa.

were stained after 12 days storage and much cellular debris was present (Plate 2 I). No detectable change in $\mathrm{pH}$ of the testicular secretion occurred throughout the storage period.

\section{Motility}

Freshly collected testicular spermatozoa were almost immotile, but rapid tail oscillations without progression were induced by increasing the $\mathrm{pH}$ from 7.0 to 8.5 with sodium hydroxide, as previously observed by Redenz (1924), or alternatively by storage in testicular fluid at $1^{\circ} \mathrm{C}$ (Table 3 ). However, motility was still well below that of ejaculated spermatozoa.

Immotility of testicular spermatozoa was not associated with a lack of energy-rich phosphate compounds as the concentrations of adenosine di- and tri-phosphate were respectively 127 and $114 \mu \mathrm{g} / 10^{9}$ ejaculated spermatozoa, compared with 105 and $152 \mu \mathrm{g} / 10^{9}$ testicular spermatozoa extracted within $1 \mathrm{hr}$ of collection. 


\section{DISCUSSION}

The development of a technique for the continuous collection of the total output of fluid and spermatozoa from the testis of a conscious animal has made possible a systematic study of factors affecting spermatozoal maturation. Copious quantities of testicular secretion can be collected and its steady rate of formation and composition together with the relatively constant output of spermatozoa from the testes of rams in a controlled environment suggest that the presence of the catheter did not impair normal function of the testis.

The discrepancy between the volume of about $40 \mathrm{ml}$ fluid secreted daily by the testis and that emerging from the epididymis (White, Larsen \& Wales, 1959), confirms the suggestion that the epididymis is a site of active fluid resorption (von Möllendorff, 1920; van Wagenen, 1924a, b; Oslund, 1926; Young, 1933; Mason \& Shaver, 1952; Nicander, 1957, 1958, 1963; Reid \& Cleland, 1957). All the evidence suggests that this may be in Nicander's regions 3 and 4 of the head of the epididymis (Nicander, 1958) where most sperm concentration takes place in the bull (Grabo \& Gustafsson, 1964) and where segmental blood flow is highest in rams (Setchell, Waites \& Till, 1964). The concentrations of sodium and potassium in testicular fluid collected from rams are very similar to those reported for bull testicular fluid (Crabo \& Gustafsson, 1964; Crabo, 1965) but the difference between these values and those reported by Scott et al. (1963) further emphasize the need for caution in interpreting the results obtained from slaughterhouse material. The higher concentration of potassium in testicular fluid than in blood plasma or testicular lymph (Wallace \& Lascelles, 1964) might be explained by a selective permeability of the peri-tubular membrane or the seminiferous epithelial cells to alkaline ions or, alternatively, there may be an exchange of sodium for intracellular potassium ions.

The present results clearly demonstrate that testicular spermatozoa depend more on oxidative metabolism when glucose is present than do ejaculated spermatozoa which are predominantly glycolytic in their mode of glucose dissimilation (Mann, 1964). Testicular spermatozoa utilize much less glucose than ejaculated cells, although a higher percentage of the glucose taken up is converted to carbon dioxide. It seems likely that in testicular spermatozoa exogenous glucose can contribute a greater share of the carbon dioxide produced. Furthermore, in contrast to ejaculated spermatozoa it is not possible to account for all the radio-active glucose utilized by testicular spermatozoa as lactate or carbon dioxide, and a considerable amount appears on the chromatogram as a spot with a mobility similar to certain amino acids.

It is particularly interesting that testicular spermatozoa stored in testicular fluid change their pattern of metabolism towards that of ejaculated spermatozoa. This suggests that certain metabolic patterns may 'mature' without the mediation of the epididymis.

There is no evidence for an active pentose cycle in either testicular or ejaculated spermatozoa; these results confirm the findings of Scott, White \& Annison (1962) for ejaculated spermatozoa and Wu et al. (1959) for epididymal spermatozoa. However, they are in contrast to the findings of Wu et al. (1959) using 
testicular spermatozoal suspensions; and it seems possible that their preparations were contaminated with testicular material since this tissue has an active pentose cycle (Bloom, 1955; Field, Pastan, Herring \& Johnson, 1960; Setchell \& Hinks, 1967).

Testicular spermatozoa withstand sudden cooling that is immediately fatal to ejaculated spermatozoa. It may be that the different lipid content of the two kinds of spermatozoa (Scott, Voglmayr \& Setchell, 1967) has some bearing on this, if resistance to cold is a property of the sperm cell membrane.

The outstanding problem is to relate the differences described between testicular and ejaculated spermatozoa with the process of maturation. Nevertheless it is clear that significant changes do occur in the biochemical characteristics of spermatozoa during their passage through the epididymis.

\section{ACKNOWLEDGMENTS}

We are grateful to Mr T. C. Dagg for preparing the plates.

\section{REFERENCES}

Bergkvist, R. \& Deutsch, A. (1954) The isolation of guanosine-5'-triphosphate from muscle. Acta chem. scand. 8, 1889.

Bishop, D. W. (1961) Biology of spermatozoa. In: Sex and Internal Secretions, 3rd edn, vol. 2, p. 707. Ed. W. C. Young. Williams \& Wilkins, Baltimore.

Bishop, M. W. H. \& WALton, A. (1960) Spermatogenesis and the structure of mammalian spermatozoa. In: Marshall's Physiology of Reproduction, 3rd edn, vol. 1, pt. 2, p. 94. Ed. A. S. Parkes. Longmans, Green, London.

Blackshaw, A. W. (1954) A bipolar rectal electrode for the production of ejaculation in sheep. Aust. vet. F. 30, 249.

Bloom, B. (1955) Catabolism of glucose by mammalian tissues. Proc. Soc. exp. Biol. Med. 88, 317.

BuHLER, D. R. (1962) A simple scintillation counting technique for assaying $\mathrm{C}^{14} \mathrm{O}_{2}$ in a Warburg flask. Analyt. Biochem. 4, 413.

CRABO, B. (1965) Studies on the composition of epididymal content in bulls and boars. Acta vet. scand. 6, Suppl. 5.

Crabo, B. \& Gustafsson, B. (1964) Distribution of sodium and potassium and its relation to sperm concentration in the epididymal plasma of the bull. F. Reprod. Fert. 7, 337.

Dawson, R. M. C., MANN, T. \& WhITE, I. G. (1957) Glycerylphosphoryl-choline and phosphorylcholine in semen, and their relation to choline. Biochem. F. 65, 627.

Dawson, R. M. C. \& Rowlands, I. W. (1959) Glycerylphosphorylcholine in the male reproductive organs of rats and guinea-pigs. Q. $\mathcal{F l}$ exp. Physiol. 44, 26.

Field, J. B., Pastan, I., Herring, B. \& Johnson, P. (1960) Studies of pathways of glucose metabolism of endocrine tissues. Endocrinology, 67, 801.

Freinkel, N., Cohen, A. K., Arky, R. A. \& Foster, A. E. (1965) Alcohol hypoglycaemia. II. A postulated mechanism of action based on experiments with rat liver slices. F. clin. Endocr. Metab. 25, 76.

Hancock, J. L. (1951) A staining technique for the study of temperature-shock in semen. Nature, Lond. $167,323$.

Hancock, J. L. (1952) The morphology of bull spermatozoa. f. exp. Biol. 29, 445.

Henle, G. \& Zitrue, C. A. (1942) Studies of the metabolism of bovine epididymal spermatozoa. Am. F. Physiol. 136, 70.

Huggett, A. St. G. \& Nixon, D. A. (1957) Use of glucose oxidase, peroxidase and o-dianisidine in determination of blood and urinary glucose. Lancet, ii, 368 .

Lardy, H. A., Hansen, R. G. \& Phillips, P. H. (1945) The metabolism of bovine epididymal spermatozoa. Archs Biochem. 6, 41.

Lundholm, L., Mohme-Lundholm, E. \& Vamos, N. (1963) Lactic acid assay with L (+) lactic acid dehydrogenase from rabbit muscle. Acta physiol. scand. 58, 243.

MAckie, T. J. \& McCARTNEY, J. E. (1949) Handbook of practical bacteriology. Livingstone, Edinburgh.

ManN, T. (1945) Anaerobic metabolism of spermatozoa. Nature, Lond. 156, 80. 
ManN, T. (1964) The biochemistry of semen and of the male reproductive tract. Methuen, London.

Mason, K. E. \& Shaver, S. L. (1952) Some functions of the caput epididymis. Ann. N.Y. Acad. Sci. 55, 585.

Newton, A. A. \& Perry, S. V. (1960) The incorporation of ${ }^{15} \mathrm{~N}$ into adenine nucleotides and their formation from inosine monophosphate by skeletal muscle preparations. Biochem. 7. 74, 127.

Newton, A. A. \& LoRd Rothschild (1961) Energy-rich phosphate compounds in bull semen: comparison of their metabolism with anaerobic heat production and impedance change frequency. Proc. R. Soc. B, 155, 183.

NiCANDER, L. (1957) On the regional histology and cytochemistry of the ductus epididymis in the rabbit. Acta morph. neerl.-scand. 1, 99.

NicANDER, L. (1958) Studies on the regional histology and cytochemistry of the ductus epididymis in stallions, rams and bulls. Acta morph. neerl.-scand. 1, 337.

Nicander, L. (1963) Resorption phenomena in the epididymis. Int. F. Fert. 8, 866.

OsLund, R. M. (1926) Ligation of vasa efferentia in rats. Am. F. Physiol. 77, 83.

Redenz, E. (1924) Versuch einer biologischen Morphologie des Nebenhodens. Arch. mikrosk. Anat. EntwMech. 103, 593.

REDENz, E. (1933) Über den Spaltungsstoffwechsel der Säugetierspermatozoen im Zusammenhang mit der Beweglichkeit. Biochem. Z. 257, 234.

Reid, B. L. \& Cleland, K. W. (1957) The structure and function of the epididymis. Aust. F. Zool. 5, 223.

Salisbury, G. W. \& Cragle, G. (1956) Freezing point depressions and mineral levels of fluids of the ruminant male reproductive tract. Proc. 3rd int. Congr. Anim. Reprod. 1, 25.

Scott, T. W., Dawson, R. M. G. \& Rowlands, I. W. (1963) Phospholipid interrelationships in rat epididymal tissue and spermatozoa. Biochem. F. 87, 507.

Scott, T. W., Voglmayr, J. K. \& SeTchell, B. P. (1967) Differences in lipid composition and metabolism between testicular and ejaculated ram spermatozoa. Biochem. F. 102, 456.

Scott, T. W., Wales, R. G., Wallace, J. C. \& White, I. G. (1963) Composition of ram epididymal and testicular fluid and the biosynthesis of glycerylphosphorylcholine by the rabbit epididymis. 7. Reprod. Fert. 6, 49.

Scott, T. W., Whrte, I. G. \& AnNison, E. F. (1962) Glucose and acetate metabolism by ram, bull, dog and fowl spermatozoa. Biochem. 7. 83, 398.

Setchell, B. P. \& Hinks, N. T. (1967) The importance of glucose in the oxidative metabolism of the testis of the conscious ram and the role of the pentose cycle. Biochem. F. 102, 623.

Setchell, B. P., Wattes, G. M. H. \& Till, A. R. (1964) Variations in flow of blood within the epididymis and testis of the sheep and rat. Nature, Lond. 203, 317.

vaN WAGENEN, G. (1924a) Degeneration of germinal epithelium in the testis of the rat as a result of the efferent duct ligation. Anat. Rec. 27(2), 189.

van WAGENEN, G. (1924b) Changes in the testis of the rat following ligation of the ductuli efferentia. Anat. Rec. 29(2), 399.

Voglmayr, J. K., Wattes, G. M. H. \& Setchell, B. P. (1966) Studies on spermatozoa and fuid collected directly from the testis of the conscious ram. Nature, Lond. 210, 861.

von MöllendorfF, W. (1920) Vitale Färbungen an tierischen Zellen. Grundlagen, Ergebnisse und Ziele biologischer Farbstoffversuche. Ergebn. Physiol. 18, 141.

Waites, G. M. H. \& Setchell, B. P. (1964) Effect of local heating on blood flow and metabolism in the testis of the conscious ram. F. Reprod. Fert. 8, 339.

Wallace, J. C. \& Lascelles, A. K. (1964) Composition of testicular and epididymal lymph in the ram. 7. Reprod. Fert. 8, 235.

WhITE, I. G. (1953) Metabolic studies of washed and diluted ram and bull spermatozoa. Aust. F. biol. Sci. 6, 706.

White, I. G. \& Wales, R. G. (1961) Comparison of epididymal and ejaculated semen of the ram. 7. Reprod. Fert. 2, 225.

White, I. G., Larsen, L. H. \& Wales, R. G. (1959) Method for the in vivo collection of epididymal spermatozoa and for their comparison with ejaculated cells. Fert. Steril. 10, 571.

Wood, H. G., KATZ, J. \& LANDAU, B. R. (1963) Estimation of pathways of carbohydrate metabolism. Biochem. Z. 338, 809.

Wu, S. H., McKenzie, F. F., Fang, S. C. \& Butrs, J. S. (1959) Pathways of glucose utilization in epididymal and testicular sperm cells. J. Dairy Sci. 42, 110.

Young, W. C. (1933) Die Resorption in den ductuli efferentes der Maus und ihre Bedeutung für das Problem der Unterbindung im Hoden-Nebenhodensystem. Z. Zellforsch. mikrosk. Anat. 17, 729. 